Original Article

\title{
PHYTOCHEMICAL SCREENING AND EVALUATION OF IN VITRO ANTIOXIDANT POTENTIAL OF IMMATURE PALMYRA PALM (BORASSUS FLABELLIFER LINN.) FRUITS
}

\author{
KRISHNAMOORTHY RENUKA, VELLAI ROSHANA DEVI, SORIMUTHU PILLAI SUBRAMANIAN*
}

Department of Biochemistry, University of Madras, Guindy Campus, Chennai 600025, Tamilnadu, India

Email: subbus2020@yahoo.co.in

Received: 06 May 2018 Revised and Accepted: 11 Jul 2018

\begin{abstract}
Objective: The present study was aimed to evaluate the in vitro antioxidant properties of immature Palmyra palm fruits which have been traditionally used for the treatment of diabetes. The qualitative phytochemical screening and quantitative estimation of total phenolic and flavonoids contents in the ethanolic extract were performed to substantiate the antioxidant and medicinal claims.

Methods: Immature palmyra palm fruits were collected, authenticated, dried and powdered in an electrical grinder. The powdered fruits were delipidated in petroleum ether and soxhilation using ethanol to extract the active ingredients. Qualitative phytochemical screening, total phenolic and flavonoid contents were carried out by established methods. The in vitro antioxidant potentials were performed by diphenyl-2-picrylhydrazyl azino-bis(3-ethylbenzothiazoline-6-sulphonic acid, nitric oxide and superoxide anion scavenging assays.

Results: The phytochemical screening showed the presence of alkaloids, flavonoids, glycosides, saponins, tannins, phytosterols, triterpenoids and phenols in the immature palmyra palm fruits extract. The total phenolic and flavonoid contents in the fruits extract was found to be $104.00 \pm 0.02 \mu \mathrm{g}$ gallic acid equivalents $/ 100 \mathrm{mg}$ of fruits extract and $98.45 \pm 0.03 \mu \mathrm{g}$ quercetin equivalents/100 mg, respectively. The percentage inhibition of DPPH radicals range from 35 to $70 \%$ at a concentration ranges from $200-1000 \mu \mathrm{g} / \mathrm{ml}$. Similarly, the percentage of inhibition of ABTS radicals was found to be in the range of 40 to $75.5 \%$. The nitric oxide scavenging activity of the fruits extract ranges from 45 to $76 \%$ whereas the superoxide radical scavenging activity ranges from 43 to $83 \%$.
\end{abstract}

Conclusion: The observed significant free radical scavenging activity along with increased total phenolic as well as flavonoid contents suggest that the immature fruits may be considered as a potential source for the identification of pharmacologically active phytochemicals capable of controlling oxidative stress.

Keywords: Borassus flabellifer Linn. Phytochemical screening, Total phenolic content, Total flavonoid content, In vitro free radicals assays

(C) 2018 The Authors. Published by Innovare Academic Sciences Pvt Ltd. This is an open access article under the CC BY license (http://creativecommons.org/licenses/by/4.0/) DOI: http://dx.doi.org/10.22159/ijpps.2018v10i8.27162

\section{INTRODUCTION}

Palmyra palm, botanically termed as Borassus flabellifer Linn. belongs to the family "Arecaceae" which is distributed widely in the tropical regions of Asian and African countries [1]. It is a slowgrowing perennial capable of living more than $150 \mathrm{y}$ and has no distinguishable features to identify the sex until flowering. The trunk with a canopy of large, fan-shaped grey-green leaves having petiole edges with hard horny spinescent serratures. Under marginal ecological conditions, the palm tree unfurls 12 leaves per year or occasionally one leaf per $28 \mathrm{~d}$ [2]. The palm tree is dioecious. Male palm produces 10-15 inflorescences each year which in turn bear 15-20 little flowers. On the other hand, each female inflorescence may have 2-3 branches which in turn possess 100-150 fruits. The palm tree starts flowering and fruiting 15-20 y after germination, during the dry season $[3,4]$.

Immature fruits are green and become dark brownish black when ripened. The fibrous, yellowish edible mesocarp pulp surrounds three and rarely one or two hard-coated seeds. The kernel of the nut contains galactomannan, sucrose, fructose, glucose and amino acids [5]. Immature endosperm is gelatinous and sweet which are consumed during the summer season to control the body heat [3]. The seeds which are sown in mound top and watered regularly germinate within two months [6]. The ripened fruit pulp is yelloworange in colour, sweet in nature with abundant carotenoids which can be eaten fresh $[7,8]$. Palmyra fruit pulp is rich in vitamin $\mathrm{A}$ and $\mathrm{C}$ and hence commercially utilized in food items and domestic feed $[9,10]$.

India stands first in the world in terms of its wealth of palmyra palms with a population of more than 125 million [11] and is commonly referred to as the "tree of life" with nearly 800 established uses including food, beverage, fibre, medicinal and timber [12]. Highly respected in Tamil culture, it is called "Karpaha Veruksham" (Celestial tree) because all its parts have a unique use [3]. Above all, due to the special contemporary significance, this tree is decreed as the official tree of Tamil Nadu in 1978 and it is being depicted in the state logo [6].

The various parts of the palmyra palm fruits have been widely used in the traditional medicine for the treatment of several ailments [13, 14]. The extract of immature Palmyra palm fruits has been widely used in the traditional medicine for the treatment of chronic diseases especially diabetes, cancer and gastrointestinal disorders $[15,16]$. In the absence of systematic reports in the scientific literature regarding the pharmacological as well as beneficial properties of immature palmyra palm fruits, the present study was aimed to qualitatively screen the phytochemicals and to evaluate its antioxidant properties by in vitro free radicals scavenging assays. The total phenolic and flavonoids contents also have been determined to substantiate the antioxidant properties of the immature fruits.

\section{MATERIALS AND METHODS}

Chemicals

Gallic acid, quercetin, Griess reagent, DPPH and ABTS were purchased from Sigma-Aldrich, St. Louis, USA. All other chemicals and reagents procured for conducting present study were of analytical grade obtained from SRL, Mumbai.

\section{Plant material}

The immature (prior to the development of endosperms) palmyra palm fruits that have weighed between 30 to 50 gm were collected 
from the trees near Chengalpet, Tamil Nadu during the month of December. The plant material was authenticated by a taxonomist at the Centre for Advanced Studies in Botany, University of Madras. A voucher specimen was deposited in the Herbarium (CAS-2017-07).

\section{Preparation of the fruits extract}

The immature fruits were washed thoroughly under running tap water and rinsed in distilled water. They were cut into slices and dried in an electric oven, powdered in an electrical grinder which was stored in an airtight container at $5{ }^{\circ} \mathrm{C}$ until further use. The powdered fruits were delipidated with petroleum ether $\left(60-80{ }^{\circ} \mathrm{C}\right)$ for overnight to selectively remove the lipids. The delipidated fruits extract was subjected to soxhalation using ethanol. The ethanolic extract of the fruits was filtered, dried and weighed. The yield was around $42 \%$.

\section{Phytochemical screening}

The ethanolic extract of immature palm fruits was subjected to phytochemical screening such as alkaloids, flavonoids, glycosides, saponins, tannins, phytosterols, triterpenoids, anthraquinones and phenols $[17,18]$. The experiments were conducted in triplicates to substantiate the findings.

\section{Determination of total phenolic content}

Total phenolic content in the ethanolic extract of immature palm fruits was determined according to the Folin-Ciocalteu colourimetric method $[19,20]$. A standard curve was drawn with gallic acid reference solutions. 2 to $10 \mathrm{ml}$ of standard aqueous gallic acid solution $(100 \mu \mathrm{g} / \mathrm{ml})$ was pipetted into a $100 \mathrm{ml}$ volumetric flask containing $70 \mathrm{ml}$ of distilled water. Folin-Ciocalteu reagent $(5 \mathrm{ml})$ and $10 \mathrm{ml}$ of saturated sodium bicarbonate solution were added and the volume was made up to $100 \mathrm{ml}$ with distilled water. The solution was thoroughly mixed. The blank was prepared in the same manner but without gallic acid. After $1 \mathrm{~h}$ of incubation at room temperature, the absorbance was measured at $760 \mathrm{~nm}$. The samples were prepared in triplicates for each analysis and the mean value was calculated. For the determination of total phenolic content in the immature palm fruits extract, aqueous solutions at the final concentration of $20 \mu \mathrm{g} / \mathrm{ml}$ were used; proceeding in the same manner described for the reference solutions and the total phenolic content was expressed as mg per gram of gallic acid equivalents.

\section{Determination of total flavonoid content}

Total flavonoid content in the ethanolic extract of immature palm fruits was determined according to the method of Quettier-Deleu $e t$ al., (2000) [21] with minor modifications. A standard curve was built with quercetin reference solutions. 2 to $8 \mathrm{ml}$ of standard quercetin $(50 \mu \mathrm{g} / \mathrm{ml})$ were pipetted into $25 \mathrm{ml}$ volumetric flasks containing 1 $\mathrm{ml}$ of $2 \%$ aluminium chloride dissolved in ethanol and the total volume was made up with ethanol. The blank was prepared by diluting $1 \mathrm{ml}$ of $2 \%$ aluminium chloride dissolved in ethanol in a 25 $\mathrm{ml}$ volumetric flask with ethanol. After 1-hour incubation at room temperature, the absorbance was measured at $420 \mathrm{~nm}$. Immature palm fruits extract were prepared at a final concentration of $20 \mu \mathrm{g} / \mathrm{ml}$, proceeding in the same manner described for the reference solutions and the total flavonoid content was calculated as quercetin equivalents from a calibration curve. The experiments were performed in triplicate for each analysis and the mean value of absorbance was recorded to determine the total flavonoid content.

\section{Free radical scavenging assays}

\section{DPPH (1, 1-diphenyl-2-picrylhydrazyl) radical scavenging assay}

The free radical scavenging capacity of the ethanolic extract of immature palm fruits extract was determined using DPPH [22]. DPPH $(200 \mu \mathrm{M})$ solution was prepared in $95 \%$ methanol. From the stock, fruits extract solution prepared in $0.1 \mathrm{~mol} \mathrm{~L}^{-1} \mathrm{Tris} \mathrm{HCl}$ buffer (pH-7.9) 200, 400, 600, 800 and $1000 \mu \mathrm{g} / \mathrm{ml}$ were taken in five test tubes. $0.5 \mathrm{ml}$ of freshly prepared DPPH solution was incubated with fruits extracts and kept under light protection for $20 \mathrm{~min}$ at room temperature. The decrease of absorbance at $517 \mathrm{~nm}$ was measured using the spectrophotometer. Deionised water used as a blank experiment and standard ascorbic acid was used as positive control. The assay was performed in triplicate and the mean value of absorbance was calculated.

$$
\% \text { scavenging activity }=\frac{\text { Absorbance of the blank-Absorbance of the sample }}{\text { Absorbance of the blank }} \times 100
$$

ABTS•+ (2, 2'-azino-bis (3-ethylbenzothiazoline-6-sulphonic acid) radical cation scavenging assay

ABTS •-radical cation scavenging activity of ethanolic extract of immature palm fruits extract was determined according to the method of Re et al., 1999 [23]. Briefly, ABTS radical cation (ABTS•+) in 20 mmol sodium acetate buffer ( $\mathrm{pH}-4.5$ ) was combined with 2.45 mmol potassium persulfate to generate a stable dark blue-green radical following $12-16 \mathrm{~h}$ of incubation at $4{ }^{\circ} \mathrm{C}$ in the dark. The reaction mixture is suitably diluted to an absorbance of $0.7 \pm 0.01$ at $734 \mathrm{~nm}$ spectrophotometrically to form the test reagent. The reaction mixture containing different concentrations (200-1000 $\mu \mathrm{g} / \mathrm{ml}$ ) of fruits extract and $3.0 \mathrm{ml}$ of test reagent were incubated in a water bath at $30{ }^{\circ} \mathrm{C}$ for $30 \mathrm{~min}$. The test solution mixture turns colourless and the absorbance is reduced due to the sequestration of unpaired electrons in the test reagent by the antioxidants in the fruits extract. Standard ascorbic acid was used as a reference. The assay was performed in triplicate and the mean value of absorbance was calculated.

\section{Assay for nitric oxide (NO) scavenging activity}

Sodium nitroprusside $(5 \mathrm{mmol})$ in phosphate buffer $\mathrm{pH} 7.7$ was incubated with $200,400,600,800$ and $1000 \mu \mathrm{g} / \mathrm{ml}$ concentrations of fruits extract dissolved in a suitable solvent (alcohol) and tubes were incubated at $25{ }^{\circ} \mathrm{C}$ for $120 \mathrm{~min}$. At intervals, $0.5 \mathrm{ml}$ of incubation solution was removed and diluted with $0.5 \mathrm{ml}$ of Griess reagent. The assay was performed in triplicate and the mean value of absorbance was calculated. The absorbance of the chromophore formed during the diazotization of nitrite with sulphanilamide and subsequent $\mathrm{N}$-napthyl ethylenediamine was measured at $546 \mathrm{~nm}$. Standard ascorbic acid was used as a reference [24].

\section{Superoxide anion (SO) radical scavenging assay}

The Superoxide radical scavenging activity of immature palm fruits extract was measured by the method of Fontana et al. (2001) [25]. In this method, the activity is measured by reduction of riboflavin/light/NBT (Nitro blue tetrazolium). The $1 \mathrm{ml}$ of reaction mixture contained phosphate buffer, NADH, NBT and various concentrations of the sample solution. The method is based on the generation of superoxide radical by autooxidation of riboflavin in the presence of light. The Superoxide radical reduces NBT to a blue coloured formazon that can be measured at $560 \mathrm{~nm}$. Standard ascorbic acid was used as a reference. The assay was performed in triplicate and the mean value of absorbance was calculated.

\section{Statistical analysis}

The results were expressed as mean \pm SD and statistical significance was evaluated by one-way analysis of variance (ANOVA) using SPSS (version 16) program followed by LSD.

\section{RESULTS AND DISCUSSION}

Table 1 shows the presence of biologically active phytochemicals such as alkaloids, flavonoids, glycosides, saponins, tannins, phytosterols, triterpenoids and phenols in the immature palmyra palm fruits extract. Phytochemicals are ecologically derived nonnutrient bioactive compounds that have the ability to exert pharmacological as well as several beneficial effects on human health. The phytochemical screening forms the basis for the quantitative estimation of bioactive constituents present in various parts of medicinal plants. The qualitative analysis of the fruits extracts evidenced that the immature fruits contain most of the important bioactive principles which readily accounts for its folklore medicinal claims. The results obtained are in accordance with the earlier reports on mesosperms [26, 27]. 
Table 1: Phytochemical screening of immature Borassus flabellifer fruits extract

\begin{tabular}{ll}
\hline Phytochemicals & Inference \\
\hline Alkaloids & + \\
Flavonoids & + \\
Glycosides & + \\
Saponins & + \\
Tannins & + \\
Anthraquinones & - \\
Phytosterols & + \\
Triterpenoids & - \\
Phenols & + \\
\hline
\end{tabular}

+indicates presence; -indicates absence; $n=3$

The palm fruits are widely used to cure a series of diseases and disorders [28-33]. Palmyra fruit pulp (PFP) obtained either from unripened or ripened fruits are available in abundance. However, they are largely unutilized owing to the presence of a bitter steroidal tetraglycoside [34, 35]. If the bitter principle is absent, the PFP is a highly nutritious additive to various foods and feeds [8]. It has been reported that the moisture content of the palmyra fruits was around $80 \%$ and it can be reduced to $6 \%$ on a dry weight basis [36]. The palm fruits are highly fibrous and it is obvious that it may be a rich source of pectins which have the high potential for use in food, cosmetics and pharmaceutical industries [37]. However, the yield and quantity of the pectins vary greatly depending on the plant source. Similarly, the polyphenolic content of the immature fruits is responsible for the bitterness and astringency [38]. The beneficial effects of polyphenols are mainly attributed to their free radical scavenging action. The diets rich in polyphenols are closely correlated with reduced incidence of metabolic and inflammatory disorders. Further, the polyphenols are known to be responsible for the colour, astringency and taste of the phytoingredients.

Saponins are a structurally and biologically diverse class of glycosides of steroids and triterpenes that are widely distributed in terrestrial plants and intimately involved in our daily lives. The structural diversity of saponins lies mainly in their sugar moieties [39-41]. The inflorescence of palmyra fruits are reported to contain a bitter compound known as flabelliferrins which belong to the class of steroidal saponins [42]. Additionally, the fruits also reported to contain flabelliferrins which are steroidal saponins with many medicinal properties [43].

The presence of alkaloids in the fruits extract is of important significance in terms of its pharmacological and beneficial effects. Alkaloids constitute an important class of structurally diversified compounds that are having a nitrogen atom in their heterocyclic ring and are derived from amino acids. Alkaloids form about $20 \%$ of plant derived secondary metabolites. They play a wide range of physiological actions on human health care such as antibiotics, anticancer and different degenerative diseases. Due to their immense pharmacological properties, alkaloids are in great demand for pharmaceutical formulations especially for the lethal diseases such as cancer and inflammatory disorders. Several synthetic and semisynthetic drugs are structural modifications of the alkaloids, which were designed to modulate the primary effect of the drugs to reduce the undesirable side effects $[44,45]$.

The presence of tannins in the fruits extract forms the basis for its medicinal value. Tannins are important plant secondary metabolites with anticarcinogenic and antimutagenic properties. The antinutritional and pharmacological effects of dietary tannins and their interactions with enzymes and other proteins have been extensively reported [46-51]. The pharmacological activity of tannins is mainly due to the presence of hydroxyl and other functional groups present in them.

Table 2 represents the total phenolic and flavonoid contents in the fruits extract. It was found to be $104.00 \pm 0.02 \mu \mathrm{g}$ gallic acid equivalents $/ 100 \mathrm{mg}$ of fruits extract and $98.45 \pm 0.03 \mu \mathrm{g}$ quercetin equivalents $/ 100 \mathrm{mg}$ of fruits extract, respectively. Phenols are very important plant constituents because of their free radicals scavenging ability which in turn due to the presence of hydroxyl groups in them [52]. Similarly, flavonoids are an important group of polyphenols widely distributed among the plant flora and containing a benzopyrone that is used as antioxidants or free radicals scavengers [53]. The significant levels of total phenolic and flavonoid contents further evidenced the presence of biologically active phytoingredients in the ethanolic extract of unripened palm fruits.

Table 2: Total flavonoid and phenolic content of immature Borassus flabellifer fruits extract

\begin{tabular}{ll}
\hline Constituents & Content \\
\hline Phenolic content & $104.00 \pm 0.02 \mu \mathrm{g}$ gallic acid equivalent/100 mg extract \\
Flavonoid content & $98.00 \pm 0.03 \mu \mathrm{g}$ quercetin equivalent/100 mg extract \\
\hline
\end{tabular}

The values are expressed as mean $\pm \mathrm{SD} ; n=3$

The in vitro DPPH and ABTS radicals scavenging activity of immature palmyra palm fruits extract was presented in fig. 1 and 2, respectively. The fruits extract scavenges the DPPH free radicals in a dosedependent manner. The percentage inhibition ranges from 35 to $70 \%$ at a concentration ranges from $200-1000 \mu \mathrm{g} / \mathrm{ml}$. Similarly, the percentage of inhibition of ABTS radicals was found to be in the range of 40 to $75.5 \%$. Among the several in vitro antioxidant assays, $\mathrm{DPPH}^{*}$ and $\mathrm{ABTS}^{*}+$ assays have been widely used as more reliable methods in determining the free radical scavenging efficacy of unknown compounds $[54,55]$. The antiradical activity assay is based on the reduction of $\mathrm{DPPH}^{*}$ in methanolic solution. Due to the presence of an odd electron, DPPH gives a strong absorption maximum at $517 \mathrm{~nm}$. As this electron becomes paired off in the presence of hydrogen donor, i.e. a free radical scavenging antioxidant, the absorption strength is decreased and the resulting decolorization is stoichiometric with respect to the number of electrons captured. It has been found that $\mathrm{DPPH}^{*}$ can oxidize cysteine, glutathione, ascorbic acid, tocopherol and polyhydroxy aromatic compounds [56]. 


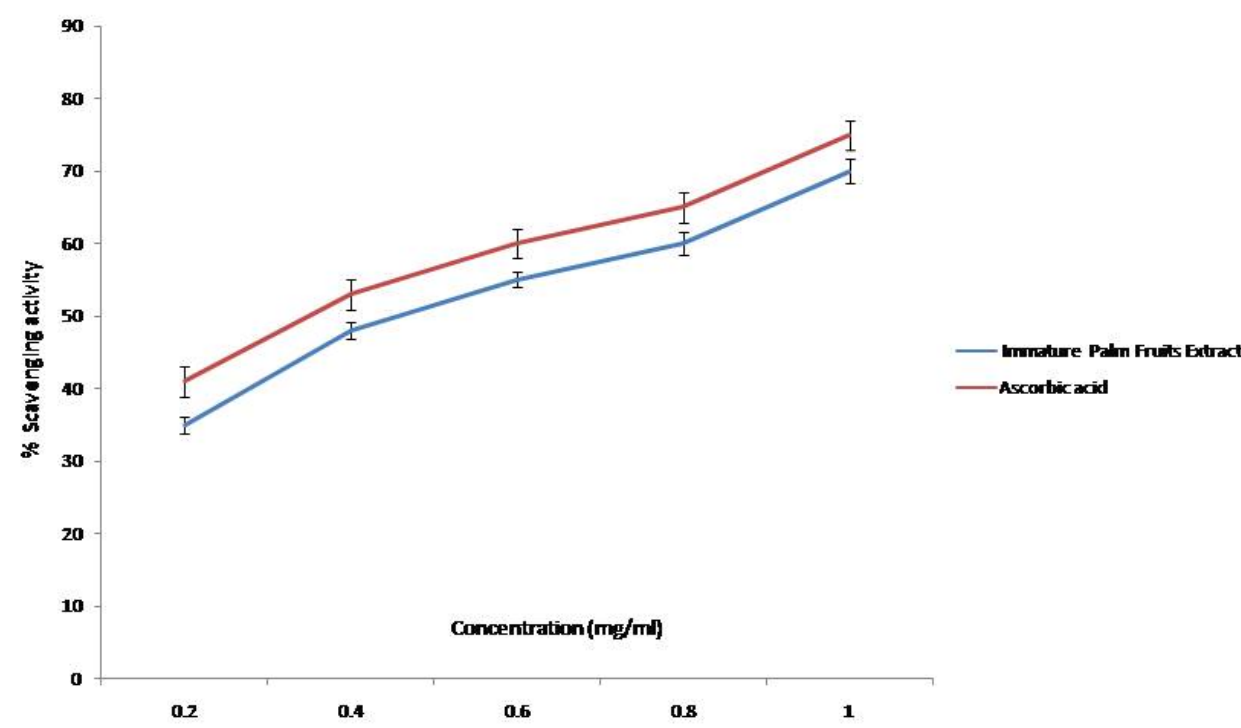

Fig. 1: DPPH radical scavenging assay of ethanolic extract of immature palm fruits. The values are expressed as mean \pm SD; $n=3$

$\mathrm{ABTS}^{*}+$ produce more powerful free radicals than $\mathrm{DPPH}^{*}$ radicals and the reactions with $\mathrm{ABTS}^{*}+$ radicals involve a single electron transfer process [57]. The principle of $\mathrm{ABTS}^{*}+$ assay is that the preformed radical monocation of $\mathrm{ABTS}^{*}+$ is generated by oxidation of $\mathrm{ABTS}^{*}+$ with potassium per sulfate and is reduced in the presence of such hydrogen-donating antioxidants.

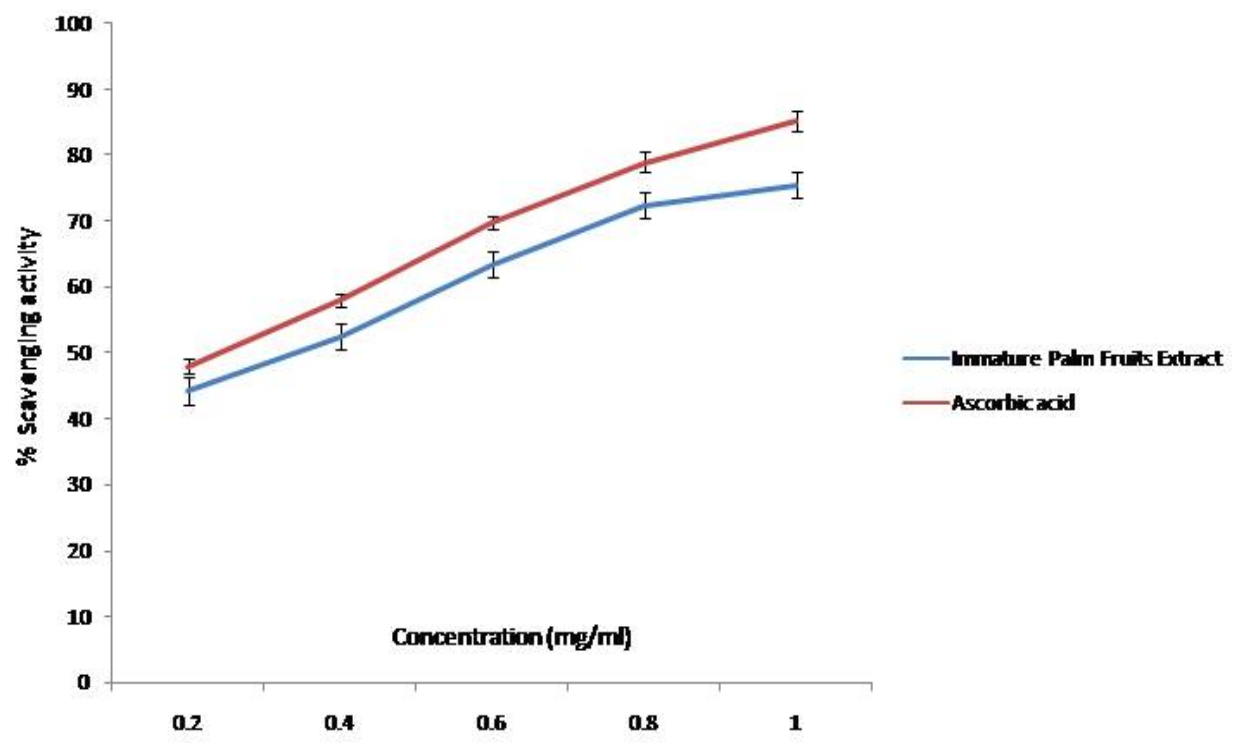

Fig. 2: ABTS radical scavenging assay of ethanolic extract of immature palm fruits. The values are expressed as mean \pm SD; $n=3$

The nitric oxide scavenging activity (fig. 3 ) of the fruits extract ranges from 45 to $76 \%$ whereas the superoxide radical scavenging activity (fig. 4) ranges from 43 to $83 \%$. Nitric oxide radicals are derived from the interaction of $\mathrm{NO}$ with oxygen or reactive oxygen species. NO is a diffusible free radical that play many roles as an effector molecule in diverse biological systems including neuronal messenger, vasodilatation, antimicrobial and antitumor activities [58]. Chronic exposure to nitric oxide radical is associated with various carcinomas and inflammatory conditions including juvenile diabetes, multiple sclerosis, arthritis and ulcerative colitis. The toxicity of NO increases greatly when it reacts with the superoxide radical, forming the highly reactive peroxynitrite anion (ONOO-). Nitric oxide has been shown to be directly scavenged by flavonoids [59].
In vitro quenching of NO radical is one of the methods that can be used to determine antioxidant activity [60]. The procedure is based on the principle that sodium nitroprusside in aqueous solution at physiological $\mathrm{pH}$ spontaneously generates nitric oxide which interacts with oxygen to produce nitrite ions that can be estimated using the Griess reagent. Scavengers of nitric oxide compete with oxygen, leading to reduced production of nitrite ions [61].

Superoxides are formed from molecular oxygen by oxidative enzymes as well as via non-enzymatic reactions such as autooxidation by catecholamines [62]. It is extremely harmful to cellular components. Superoxide anions play an important role in the formation of other reactive oxygen species such as hydrogen peroxide, hydroxyl radical and singlet oxygen, which readily induce oxidative damage in lipids, protein and DNA [63]. 


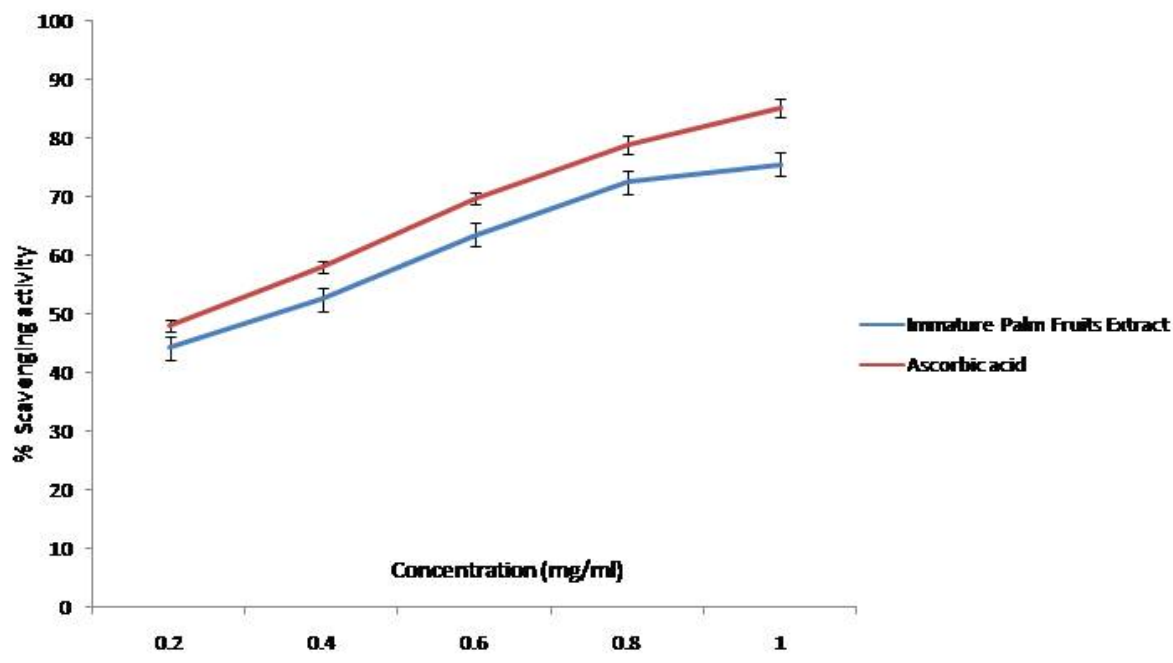

Fig. 3: Nitric oxide scavenging assay of ethanolic extract of immature palm fruits, the values are expressed as mean \pm SD; $n=3$

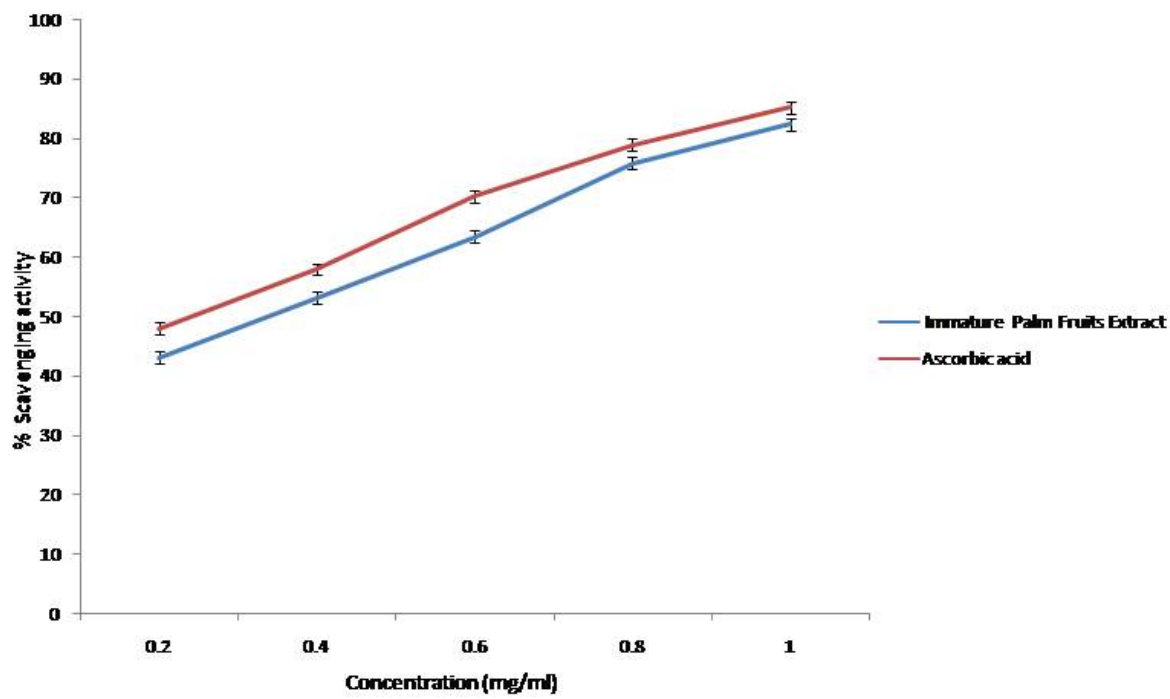

Fig. 4: Superoxide radical scavenging assay of ethanolic extract of immature palm fruits, the values are expressed as mean \pm SD; $n=3$

Superoxide, which is an anion radical, is produced by the one-electron reduction of molecular oxygen. In aqueous media, protonation of superoxide can form the uncharged hydroperoxyl radical (HOO•), which exhibits a pKa of 4.8, meaning that the anion radical form is by far the predominant species at physiological $\mathrm{pH}$ ranges. A second reduction of superoxide would require the energetically disfavored compression of two full negative charges on a diatomic molecule. As a result, superoxide is generally a better reducing agent than the oxidizing agent. In addition, superoxide does not cross lipid membranes readily. Superoxide is relatively unreactive toward most biological molecules, although the low levels of superoxide permitted in cells and tissues indicate that limiting cell exposures to superoxide is a significant selector for survival. The levels of superoxide are kept low by effective compartmentalization of the sequential reductions of oxygen and by extensive expressions of superoxide dismutases with high affinities for superoxide [64]. The observed significant in vitro antioxidant properties of the fruits extract may be due to the increased levels of phenolic and flavonoids present in them [65].

\section{CONCLUSION}

A thorough literature survey revealed that the reports involving the pharmacological properties of immature palmyra palm fruits are sparse. The results of the present study evidenced the presence of pharmacologically active phytochemicals in the ethanolic extract of immature palmyra palm fruits. The total phenolic and flavonoid contents readily account for the in vitro free radical scavenging activity of the fruits extract. Thus, it can be concluded that the immature fruits extract may be considered as a rich source for the identification of nutraceuticals with diversified medicinal values. From the data obtained, it can be concluded that the immature fruits extract may be considered as a potential source of antioxidants.

\section{AUTHORS CONTRIBUTIONS}

All the author have contributed equally

\section{CONFLICT OF INTERESTS}

All the authors have equal contribution in the manuscript and declare no conflict of interests.

\section{REFERENCES}

1. Artnarong $\mathrm{S}$, Masniyom $\mathrm{P}$, Maneesri J. Isolation of yeast and acetic acid bacteria from palmyra palm fruit pulp Borassus flabellifer linn. Int Food Res J 2016;23:1308-14.

2. Morton JF. Notes on distribution, propagation, and products of Borassus palms. Econ Bot 1988;42:420-41.

3. Ramachandran VS, Swarupanandan K, Renuka C. A traditional irrigation system using palmyra palm Borassus flabellifer in Kerala, India. Palms 2004;48:175-81. 
4. Saranya O, Vijayakumar TP. Preliminary phytochemical screening of raw and thermally processed palmyra palm (Borassus flabellifer linn.) fruit pulp. J Innov Pharm Bio Sci 2016;3:186-93.

5. Sharma PC, Yelne MB, Denis TJ. Data base on medicinal plants used in ayurveda. Central Council Res Ayurveda Siddha 2000;5:304

6. Saravanya KS, Kavitha S. A study on properties of palmyra sprout. Int J Curr Res 2017:9:54299-301.

7. Theivendirarajah K, Chrystopher RK. Alcohol from palmyrah palm Borassus Flabellifer L. fruit pulp. Vingnanam J Sci 1986;1:44-6.

8. Ariyasena DD, Jansz ER, Jayesekera S, Abeysekara AM. Inhibitory effect of the bitter principle of Palmyra Borassus flabellifer L fruit pulp on the growth of mice: evidence using bitter and non-bitter fruit pulp. J Sci Food Agric 2000;80:1763-6.

9. Chakraborty I, Chaurasiya AK, Saha J. Quality of diversified value addition from some minor fruits. J Food Sci Technol 2011;48:750-4.

10. Vengaiah PC, Vijaya Kumara B, Murthy GN, Prasad KR. Physicochemical properties of palmyrah fruit Pulp (Borassus flabellifer L). J Nutr Food Sci 2015;5:391-5.

11. Vengaiah PC, Murthy GN, Prasad KR, Kumari KU. Post-harvest technology of palmyra (Borassus flabellifer L) present practises and scope. International conference on food processing by omics group, India; 2012.

12. Arulraj S, Augustine BJ. Underutilized palms. In: Peter KV. Ed. Underutilized and underexploited horticultural crops. New India Publishing Agency 2008;3:415-29.

13. Paschapur MS, Patil S, Patil SR, Kumar R, Patil MB. Evaluation of the analgesic and antipyretic activities of ethanolic extract of male flower inflorescences of Borassus flabellifer L. Arecaceae. Int J Pharm Pharm Sci 2009a;1:98-106.

14. Paschapur MS, Patil MB, Kumar R, Patil SR. Evaluation of antiinflammatory activity of ethanolic extract of Borassus flabellifer L. male flowers (inflorescences) in experimental animals. J Med Plants Res 2009b;3:49.

15. Revesz L, Hiestand P, La Vecchia L, Naef R, Naegeli HU, Oberer $\mathrm{L}$, et al. Isolation and synthesis of a novel immunosuppressive 17alpha-substituted dammarane from the flour of the Palmyrah palm Borassus flabellifer. Bioorg Med Chem Lett 1999;9:1521-6.

16. Paschapur MS, Patil MB, Kumar R, Patil SR. Influence of ethanolic extract of Borassus flabellifer L. male flowers inflorescences on chemically induced acute inflammation and polyarthritis in rats. Int J PharmTech Res 2000;1:551.

17. Harbone JB. Phytochemical Methods. London: Chapman and Hall; 1998. p. 117-9.

18. Kokate CK, Purohit AP, Gokhale SB. Drugs containing glycosides, drugs containing tannins, lipids and protein alkaloids. Text Book of Pharmacognosy: Carbohydrate and Derived Products. 7th ed. India: Nitrali Prakashan; 2001. p. 133-66, 167-254, 255-269, 272-310, 428-523.

19. Singleton VL, Orthofer R, Lamuela-Raventos RM. Analysis of total phenols and other oxidation substrates and antioxidants by means of folin-ciocalteu reagent. Methods Enzymol 1999;299:152-78.

20. Kumazawa S, Taniguchi M, Suzuki Y, Shimura MK, Kwon MS, Nakayama T. Antioxidant activity of polyphenols in carob pods. J Agric Food Chem 2002;50:373-7.

21. Quettier-Deleu C, Gressier B, Vasseur J, Dine T, Brunet C, Luyckx M, et al. Phenolic compounds and antioxidant activities of buckwheat Fagopyrum esculentum Moench hulls and flour. J Ethnopharmacol 2000;72:35-42.

22. Brand Williams W, Cuvelier ME, Berset C. Use of a free-radical method to evaluate antioxidant activity. Food Sci Technol Leb 1995;28:25-30.

23. Re R, Pellegrini N, Proteggente A, Pannala A, Yang M, Rice Evans C. Antioxidant activity applying an improved ABTS radical cation decolourization assay. Free Radical Biol Med 1999;26:1231-7.

24. Marcocci L, Maguire JJ, Droylefaix MT, Packer L. The nitric oxide scavenging properties of Ginkgo biloba extract EGb 761. Biochem Biophys Res Commun 1994;201:748-55.
25. Fontana M, Mosca L, Rosei MA. Interaction of enkephalines with oxyradicals. Biochem Pharmacol 2001;61:1253-7.

26. Singchai B, Kansane K, Chourykaew B. Phytochemical screening and biological activities of Borassus flabellifer L. Asian J Pharm Clin Res 2015;8:151-3.

27. Sarkodie AJ, Squire AS, Kretchy AI. Borassus aethiopum, a potential medicinal source of antioxidants, anti-inflammatory and antimicrobial agents. Herb Med 2015;2:1.

28. Hamill FA, Apio S, Mubiru NK, Bukenya-Ziraba R, Mosango M, Maganyic OW, et al. Traditional herbal drugs of Southern Uganda, II: literature analysis and antimicrobial assays. J Ethnopharmacol 2003;84:57-78.

29. Betti JL. An ethnobotanical study of medicinal plants among the Baka Pygmies in the Dja Biospehere Reserve, Cameroon. Afr Study Monogr 2004;25:1-27.

30. Zambrana NYP, Byg A, Svenning JC, Moraes M, Grandez C, Balslev H. Diversity of palm uses in the western Amazon. Biodiversity Conservation 2007;16:2771-8.

31. Nadembega P, Boussim JI, Nikiema JB, Poli F, Antognoni F Medicinal plants in Baskoure, Kourittenga province, Burkina Faso: an ethnobotanical study. J Ethnopharmacol 2011;133:378-95.

32. Macía MJ, Armesilla PJ, Camara Leret R, Paniagua Zambrana N, Villalba S, Balslev $\mathrm{H}$, et al. Palm uses in northwestern South America: a quantitative review. Bot Rev 2011;77:462-570.

33. Gruca M, Blach-Overgaard A, Balslev H. African palm ethnomedicine. J Ethnopharmacol 2015;165:227-37.

34. Theivendirarajah K. Palmyrah fruit products on processing Palmyrah Development Board, Sri Lanka, Bulletin; 1992. p. 1-20.

35. Jansz ER, Nikawala JK, Gooneratne J, Theivendirarajah K. Studies on bitter principle and debittering of palmyrah fruit pulp. J Sci Food Agric 1994;65:185-9.

36. Wijewardana RMNA, Nawarathne SB, Wickramasinghe I. Effect of various dehydration methods on proximate composition and retention of antioxidants in different fruit powders. Int Food Res J 2016;23:2016-20.

37. Tamaki Y, Konishi T, Fukuta M, Tako M. Isolation and structural characterisation of pectin from endocarp of Citrus depressab. Food Chem 2008;107:352-61.

38. Phaichamnan M, Posri W, Meenune M. Quality profile of palm sugar concentrate produced in Songkhla province, Thailand. Int Food Res J 2010;17:425-32.

39. Hostettmann K, Marston A. Saponins. Cambridge University Press: Cambridge; 1995.

40. Rouhi AM. Atom economical reactions help chemists eliminate waste. Chem Eng News 1995;11:28.

41. Waller GR, Yamasalki K. eds. Advances in experimental medicine and biology. Saponins Used in Traditional and Modern Medicine. Plenum Press: New York; 1996. p. 404.

42. Masayuki Y, Fengming Xu. New spirostane-type steroid saponins with antidiabetogenic activity from Borassus flabellifer. Chem Pharm Bull 2007;55:308-16.

43. Sandhya S, Sudhakar K, David Banji Rao KNV. Harmacognostical standardization of Borassus flabellifer root. Ann Biol Res 2010;1:85-94.

44. Babbar N. An introduction to alkaloids and their applications in pharmaceutical chemistry. Pharm Innov J 2015;4:74-5.

45. Kaur R, Arora S. Alkaloids-important therapeutic secondary metabolites of plant origin. J Crit Rev 2015;2:1-8.

46. Price ML, Butler LG. Tannins and Nutrition. Purdue Univ Agric Exp Stn Bull No. 282, Lafayette, Indiana; 1980.

47. Salunkhe DK, Jadhav SJ, Kadam SS, Chavan JK. Chemical, the biochemical and biological significance of polyphenols in cereals and legumes. CRC Crit Rev Food Sci Nutr 1982;17:277.

48. Deshpande SS, Sathe SK, Salunkhe DK. Chemistry and safety of plant phenols. Adv Exp Med Biol 1984:177:457.

49. Butler LG, Riedl DJ, Lebryk DG, Blytt HJ. Interaction of proteins with sorghum tannin: mechanism, specificity and significance. J Am Oil Chem 1984;61:916.

50. Reddy NR, Pierson MD, Sathe SK, Salunkhe DK. Dry bean tannins: a review of nutritional implications. J Am Oil Chem Soc 1985;62:541.

51. Butler LG, Roglers JC, Mehansho H, Carlson DM. Dietary effects of tannins. In: Plant Flavonoids in Biology and Medicine: Biochemical, Pharamacological and Structure-Activity Relationships. Alan R. Liss, New York; 1986. p. 141. 
52. Kumar S, Pooja M, Harika K, Hiawatha E, Nagabhushanamma G, Vidyavathi N. In vitro antioxidant activities, total phenolics and flavonoid contents of whole plant of Hemidesmus indicus Linn. Asian J Pharm Clin 2013;6:249-51.

53. Somit D, Priyankar D, Kumar CT. Quantification and correlation of the bioactive phytochemicals of Croton bonplandianum leaves of sub-Himalayan region of West Bengal. Asian J Pharm Clin Res 2013;6:142-7.

54. Kang HS, Kim KR, Jun EM, Park SH, Lee TS, Suh JW, et al. Cyathuscavins $\mathrm{A}, \mathrm{B}$, and $\mathrm{C}$, new free radical scavengers with DNA protection activity from the Basidiomycete Cyathus stercoreus. Bioorg Med Chem Lett 2008;18:4047-50.

55. Lu JM, Lin PH, Yao Q Chen C. Chemical and molecula mechanisms of antioxidants: experimental approaches and model systems. J Cell Mol Med 2010;14:840-60.

56. Nishizawa M, Kohno M, Nishimura M, Kitagawa A, Niwano Y Non-reductive scavenging of 1,1-diphenyl-2-picrylhydrazyl (DPPH) by peroxyradical: a useful method for quantitative analysis of peroxyradical. Chem Pharm Bull 2005;53:714-6.

57. Luo J, Quan J, Tsai J, Hobensack CK, Sullivan C, Hector R, et al. Nongenetic mouse models of non-insulin-dependent diabetes mellitus. Metabolism 1998;47:663-8.
58. Bhaskar HV, Balakrishnan N. In vitro antioxidant property of laticiferous plant species from Western Ghats Tamilnadu, India. Int J Health Res 2009;2:163-70.

59. Lakhanpal P, Rai DK. Quercetin: a versatile flavonoid. Int J Med Update 2007;2:22-37.

60. Nagmoti DM, Khatri DK, Juvekar PR, Juvekar AR. Antioxidant activity and free radical-scavenging potential of Pithecellobium dulce Benth seed extracts. Free Radical Antioxidants 2011;2:37-43.

61. Ebrahimzadeh MA, Nabavi SM, Nabavi SF, Bahramian $F$ Bekhradnia AR. Antioxidant and free radical scavenging activity of $H$. officinalis $\mathrm{L}$. var. angustifolius, $V$. odorata, $B$. hyrcana and C. speciosum. Pakistan J Pharm Sci 2010;23:29-34.

62. Hemmami T, Parihar MS. Reactive oxygen damage. Ind J Physiol Pharmacol 1998;42:440-52.

63. Pietta PG. Flavonoids as antioxidants. J Nat Prod 2000;63:1035-42

64. Okado Matsumoto A, Fridovich I. Subcellular distribution of superoxide dismutases (SOD) in rat liver: $\mathrm{Cu}, \mathrm{Zn}-\mathrm{SOD}$ in mitochondria. J Biol Chem 2001;276:38388-93.

65. Ayoub Z, Mehta A. Medicinal plants as potential source of antioxidant agents: a review. Asian J Pharm Clin Res 2018;11:50-6. 